\title{
Chapter 26 \\ Urban Agriculture for Urban Regeneration in the Sustainable City
}

\author{
François Mancebo
}

Dense cities are often perceived as universal models for urban transition to sustainability (Williams et al. 2000). Of course, there is a strong case for considering high urban density as a requisite for sustainability, if only because sustainability usually means making a better use of what is already there-for example, recycling the urban fabric and urban functions without going through phases of degraded neighbourhoods (Whitehead 2003). This is all well and good, but it should be accepted nevertheless that low urban density offers some advantages as far as sustainability is concerned. It reduces the concentration of nuisances and pollution and lowers the density of urban centres that are sometimes on the brink of congestion (Neuman 2015). Besides, climate policies introduce new arguments for low-density urbanizations. Green neighbourhoods planted with trees presenting a high water loss coefficient can lower the local temperature (Boutefeu 2007). In low-density areas, more square metres of roof per household are available than in high-density areas; thus, generalized photovoltaic roofs can be significant. Such facts compel us to cast an eye without prejudice on the very notion of sustainable city, which does not consider from the start that "sustainable" means "dense".

Furthermore, sustainability cannot be addressed within the limits of the urban centres. For example, any city - be it sustainable or not-has to provide water and energy to its inhabitants while reducing pollution and processing all the urban waste (Elliot 2006). Beyond all the well-known technical solutions - smart grids, selective sorting, urban heating, wastewater treatment plants, intelligent buildings, etc.- - the energy, the resources, the water, and the food still come from outside the city limits. Sewage plants and garbage dumps are also outside. Even a large number of people working in the city live outside, when they cannot afford to live anymore in the expensive-and sometimes gentrified-densely built city (Burton 2001). Cities

\footnotetext{
F. Mancebo $(\bowtie)$

IATEUR International Research Center on Sustainability (IRCS), Rheims University,

Rheims, France

e-mail: francois.mancebo@univ-reims.fr
} 
benefit from what David Pearce calls imported sustainability (Pearce et al. 1989), that is, when an unsustainable place looks sustainable by giving to other places the burden of its sustainability: exporting pollution and polluting activities while siphoning resources. Thus, it is not possible to address urban sustainability issues by considering only urbanized areas and densely built urban centres. It is crucial to design sustainability across areas large enough to include most of the fluxes of the urban metabolism, which means areas encompassing suburban, peri-urban, and dependent rural or natural places (Wheeler 2004).

As a matter of fact, the social, economic, and cultural transformations of the last few decades have produced deep changes in how people live. Today, urban areas have either no boundaries or very fuzzy ones, as shown by Bernardo Secchi with the notion of Citta Diffusa (Secchi 2002) or by Thomas Sieverts with the notion of Zwischenstadt (Sieverts 1997). Why on earth are we supposed to set up a false dichotomy between urban and rural area, given that lifestyle, facilities, and amenities are not so different? Time has arrived to think different: No, high urban density is not the be all and end all of transition to sustainability. No, it is not possible to address urban sustainability issues by considering only urban centres. The whole rural-urban continuum has to be addressed.

Is there already a new type of urban arrangement, that if generalized would deeply transform the city while contributing to a more sustainable future all through the rural-urban continuum? Yes, there is one, and its name is urban agriculture: a way of counteracting urban sprawl by what could be called "rural sprawl", via the introduction of rural characteristics such as farming within the city.

\section{Different Types of Urban Agriculture, Not All Sustainable}

What do we really call urban agriculture? Urban agriculture looks first like an oxymoronic and elusive term (www.fao.org/docrep/003/w1358e/w1358e07.htm). Urban agriculture is not only about food and landscapes, and urban agriculture production can certainly not be sufficient to feed a whole urban area, anyway. What specific services may urban agriculture bring to a city and what nuisances and unexpected consequences may result are important though too often dodged issues.

Basically, urban agriculture is the practice of cultivating, processing, and distributing food in a city (Bailkey and Nasr 2006). This notwithstanding, there are very different types of urban agriculture that don't have much in common except that all are about growing edible plants: intensive vertical farming, micro-farming, kitchen and community gardens, etc.

Let's consider vertical farming - cultivating plants or breeding animals within tall greenhouse buildings or vertically inclined surfaces (Hough 1995). Vertical farming takes form in several ways: crops being grown in along the interior floors of mid-rise buildings, 30-foot apparatuses that rotate crops on belts (http://www. verticalfarm.com/), rooftop farming, tree-like skyscrapers, and agritectures (http:// 
agritecture.com/). The point of this farming laden with eco-technologies is exploiting synergies between the built environment and intensive-if not industrial-agriculture (Caplow 2009), with recirculating hydroponics and aeroponics that significantly reduce the amount of water needed, systems to collect rain and treat wastewater, producing photovoltaic green energy, etc. (Brown 2012).

But let's go back to the source of modern vertical farming. Dickson Despommier started using the term in 1999, first to qualify the cultivation of plants on flat roofs and then inside retrofitted empty mid-rise buildings (Despommier 2010). And, by the way, it was Gilbert Ellis Bailey who first coined the term "vertical farming" in 1915, long before anybody heard about sustainability (Bailey 1915). This is quite different from the brand new smart buildings - tree-like skyscrapers and high-rise agritectures-proposed today as the paragon of urban agriculture. Besides, these projects remain projects: no one was ever built, which says a lot about their feasibility (Vogel 2008). In real life, vertical farmers are far more modest and much closer to Despommier's intuition: three-story building, with solar panels on its roof in the South Korean city of Suwon and three floors underground in the city of Den Bosch in the Netherlands, cultivated without sunlight by a private company-PlantLab.

As beautifully put by Stan Cox and David Van Tassel, modern vertical farming looks like a dreamy idea with a solid financial and political hidden agenda that would ultimately become more industrialized than traditional agriculture (Cox and Van Tassel 2010). Such a type of urban agriculture is all but sustainable.

For example, there are many good reasons why high-rise buildings do not already have trees. Nearly every climate variable is more extreme than at street level. As mentioned by Tim De Chant: "If-and it's a big if-any of these buildings ever get built, odds are they'll be stripped of their foliage quicker than a developer can say 'return on investment"' (De Chant 2013). Besides, how are these trees going to be watered and fertilized? Concerning cattle, what would be the real productivity of such farms, when a single cow needs more than 1.5 ha of grassland in its life. And, well, even vegetable crops grow better on natural soil than indoors or on roofs (Ladner 2011). As a matter of fact, generalizing vertical farms would require significant technological breakthroughs. As pointed out by Saskia Sassen, it is not feasible simply to plop down a new technology in an urban space (Sassen 2011). How the urban fabric may be inclusive of this type of farming?

When trying to determine if urban agriculture may contribute to a sustainable future, the first question to ask is: will this agriculture be at the service of the inhabitants-and not the other way around. Indeed, it is crucial to keep in mind that the "environment", far from being pure transcendence, is embedded in societies (Hajer and Versteeg 2005). Thus, to address urban sustainability, it is crucial to know what a "good environment" is for the people and the communities living there: one in which the enhancement of environmental conditions stricto sensu (water quality, air, biodiversity, prudent use of resources, land and energy, etc.) improves living conditions and facilitates new lifestyles (Mancebo 2013). The success of urban agriculture depends on its local ownership by the people (Greenfield 2013). 


\section{Urban Agriculture Is a Common Good}

All of the above leads to consider that to design a more sustainable future in the rural-urban continuum, we should rather focus on a more traditional type of urban agriculture made of community gardens, kitchen gardens, crofting and microfarming, land sharing, low-rise rooftop gardens, or schoolyard greenhouses-which are different things but strongly linked to each other, not least because they develop the potential for people to exercise significant influence over the place where they live (Mougeot 2005). The point is bringing longer-lasting change, in the spirit of Rob Hopkins' Transition Towns (Hopkins 2008).

This urban agriculture varies a lot according to the climate, the cultural background, and the economic and social situation of the city. In many urban areas of Central America or India, urban agriculture is essentially a food security issue, related to fight against poverty and malnutrition (Smit et al. 1996). The situation is quite different in European (Fleury and Donadieu 1997) or North American cities (Reyburn 2002). There, urban agriculture is mainly seen as a social innovation that contributes to improving the quality of life, fostering social links among neighbours, and enhancing urban landscapes. For example, many official urban agricultural projects result from "greening" agendas, created under the umbrella of the "Green New Deal" which aims to address global warming and financial crises rather than food issues as mentioned by Tim Jackson (Jackson 2009). In many other cities, the landscaping aspect and recreational dimension are highlighted.

In any event, all these urban agricultures-whatever their forms, their goals, and their means-share significantly common features, which result from the fact that they have been there since time immemorial, from the very beginning of the cities actually (Jacobs 1969). In medieval times, when walls and defensive structures left out most of the farmland, agricultural patches were available inside the city and next to the city walls (Cockrall-King 2012).

Thus, urban agriculture is not such a fresh idea. Moreover, it is certainly not an offspring of sustainable development. It has existed for a long time, in very different places around the world, such as the chinampas in Tenochtitlan, the actual Mexico city, since the fifteenth century or sooner (Torres-Lima et al. 1994); the hortillonnages in Amiens, a French city north of Paris, for more than twenty centuries (Clauzel 2008); or the interstitial gardens (agriculture d'interstice) of Yaoundé, Cameroon's capital, which accompanied the foundation of the city in the nineteenth century (Dauvergne 2011). Indigenous people in South America have long used vertically layered growing techniques within their cities, and the rice terraces of East Asia follow the same principle, as were the hanging gardens of Babylon, thousands of years ago.

But while cities and agriculture have long been inseparable and mutually reinforcing, everything changed during the twentieth century: increased mobility and progressive globalization made pointless the previous need for geographical proximity between the farmers and the urban consumers. Farming was more or less banned from the city, under the combined forces of urbanization and planning 
regulation (Tornaghi 2014). The new craze for urban agriculture, in the form that we are dealing with in this paper, began 20 years ago. It renewed—but also transformed deeply - the old tradition of nineteenth-century backyard gardens. Beyond allotment gardening, urban agriculture is appearing in front lawns, kitchen gardens, pavement verges, railway embankments, and any interstitial spaces. In many ways, the citizens involved in urban agriculture claim ownership over the city and particularly over the policies and projects developed by the city (Reynolds 2008).

In this sense urban agriculture proposes a radical remaking of the urban, which breaks with the urban-rural dichotomy and paves the way to a reinvention of the urban form. One among the many challenges of urban sustainability is re-establishing the inclusiveness of the urban fabric instead of just popping up parks, green spaces, or smart buildings: the current regional master plan of Paris proposes-as an important means to foster sustainability - a quantitative objective of $10 \mathrm{~m}^{2}$ of public green area per inhabitant, as though it were sufficient to display "green" to become suddenly sustainable. Shocking but understandable, mayors, representatives, and more generally elected officials adore showcasing actions that are very visible. They are less interested in citizen ownership and holistic approaches, which are more important to make the city sustainable but harder to implement and less profitable as an electoral issue.

All things considered, when trying to make a city sustainable, there may be some good sense in promoting urban agriculture instead of manicured sophisticated green areas (McKay 2011). But, promoting urban agriculture is not enough. The point is rather that this urban agriculture be considered a common good, bringing people together and reshaping the whole urban fabric (Hodkinson 2012). Is it doable, and if so how? Urban agriculture "works better" when no public or private actor explains to the population what the procedure should be and how people should act. To say it otherwise, it looks like it "works better" when the inhabitants transform their living environment outside of any legal framework or official urban project. France's Trames Vertes et Bleues (Green and Blue Grids) is a wonderful counterexample. Trames Vertes et Bleues is a land management tool for the preservation of biodiversity - especially in urban and peri-urban areas-whose procedure was too formal and technocratic. Nobody asked the local communities and the inhabitants for their views. Thus, in many places, its implementation turned confrontational and resulted finally in inconsistent and incomplete grids (Blanc 2009).

\section{Conclusion}

As I discussed in a recent paper, a city does not arise from the sole will and skill of architects, planners, surveyors, and politicians (Mancebo 2015). It has to be nurtured and moulded by its inhabitants. Such a process needs time. Quite differently from the frenetic timeline and knee-jerk reactions to any opposition that elected officials and planners, guided by their own short-term interests (the next election, compliance with construction deadlines etc.), impose on urban policies, it would make sense to establish — or maintain — productive lands at the core of urban design. 
All the more since agricultural plots are often temporary-not to say ephemeraland eventually disappear under the pressure of urban growth, urban densification, and increased property value (Sandstrom 2002). We definitely have a long way to go in including agriculture in urban planning on a permanent basis, but it is worth the effort. For-let there be no mistake about it —urban agriculture has an unexplored potential to foster resilient cities.

\section{References}

Bailey GE (1915) Vertical farming. E. I. Dupont de Nemours Powder Co, Wilmington

Bailkey M, Nasr J (2006) From Brownfields to Greenfields: producing food in North American cities. Commun Food Secur News 2000:6

Blanc N (2009) Vers un urbanisme écologique ? URBIA 8:39-59

Boutefeu E (2007) Végétaliser les villes pour atténuer les îlots de chaleur urbains, CERTU

Brown L (2012) Full planet, empty plate: the new geopolitics of food scarcity. W. W. Norton \& Company, New York, NY

Burton E (2001) The compact city and social justice. In Housing Studies Association Spring Conference, University of York

Caplow T (2009) Building integrated agriculture: philosophy and practice. Heinrich Böll Foundation: urban development and urban lifestyles of the future, pp 48-51

Clauzel C (2008) Mutations des hortillonnages d'Amiens vers une agriculture multifonctionnelle et urbaine. Économies et Sociétés 42(11-12):2297-2307

Cockrall-King J (2012) Food and the city. Prometheus Books, Amherst, NY

Cox S, Van Tassel D (2010) Vertical farming doesn't stack up. Synthesis/Regeneration 52:4-6

Dauvergne S (2011) Dynamique des agricultures périurbaines en Afrique sub-saharienne et statuts fonciers le cas des villes d'Accra et Yaounde. PhD thesis, ENS Lyon

De Chant T (2013) Can we please stop drawing trees on top of skyscrapers? ArchDaily - https:// www.archdaily.com/346374/can-we-please-stop-drawing-trees-on-top-of-skyscrapers

Despommier D (2010) The vertical farm: feeding the world in the 21st century. Thomas Dunne Books/St. Martin's, New York, NY

Elliot J (2006) An introduction to sustainable development. Routledge, Evanston, IL

Fleury A, Donadieu P (1997) De l'agriculture périurbaine à l'agriculture urbaine. Le Courrier de l'Environnement 31:45-61

Greenfield A (2013) Against the smart city (the city is here for you to use). Verso, New York, NY

Hajer M, Versteeg W (2005) A decade of discourse analysis of environmental politics: achievements, challenges, perspectives. J Environ Policy Plan 7(3):175-184

Hodkinson SN (2012) The new urban enclosures. City Anal Urban Trends Cult Theory Policy Action 16(5):500-518

Hopkins R (2008) The transition handbook. UIT Cambridge, Cambridge

Hough M (1995) Cities and natural process: a basis for sustainability to city farming. Routledge, Evanston, IL

Jackson T (2009) Prosperity without growth: economics for a finite planet. Earthscan, London

Jacobs J (1969) The economy of the city. Random House, New York, NY

Ladner P (2011) The urban food revolution: changing the way we feed cities. New Society Publishers, Vancouver

Mancebo F (2013) The pitfalls of sustainability policies: insights into plural sustainabilities. Challenges Sustainy 1(1):29-40

Mancebo F (2015) Combining sustainability and social justice in the Paris metropolitan region. In: Isenhour C, McDonough G, Checker M (eds) Sustainability in the global city: myth and 
practice, Series new directions in sustainability. Cambridge University Press, Cambridge, pp 263-283

McKay G (2011) Radical gardening. Frances Lincoln, London

Mougeot L (2005) Agropolis: the social, political and environmental dimensions of urban agriculture. Earthscan, London

Neuman M (2015) The compact city fallacy. J Plan Educ Res 25:11-26

Pearce D, Markandya A, Barbier EB (1989) Blueprint for a green economy. Earthscan, London

Reyburn S (2002) Le cadre de vie et les jardins communautaires à Montréal. VertigO, New York, NY

Reynolds R (2008) On guerrilla gardening: a handbook for gardening without boundaries. Bloomsbury, London

Sandstrom U (2002) Green infrastructure planning in urban Sweden. Plan Pract Res 17(4):373-385

Sassen S (2011) Talking back to your intelligent city. McKinsey On Society, New York, NY

Secchi B (2002) L'émergence de la ville diffuse. Diagonal 156:10-12

Sieverts T (1997) Zwischenstadt. Zwischen Ort und Welt, Raum und Zeit, Stadt und Land. Vieweg, Decatur, IL

Smit J, Ratta A, Nasr J (1996) Urban agriculture: food, jobs and sustainable cities, Series for habitat II, vol 1. UNDP, New York, NY

Tornaghi C (2014) Critical geography of urban agriculture. Prog Hum Geogr 38(4):551-567

Torres-Lima P, Canabal-Cristiani B, Burela-Rueda G (1994) Urban sustainable agriculture: the paradox of the chinampa system in Mexico City. Agric Hum Values 11(1):37-46

Vogel G (2008) Upending the traditional farm. Science 319(5864):752-753

Wheeler S (2004) The sustainable urban development reader, Urban Reader Series. Routledge, Evanston, IL

Whitehead M (2003) (Re)analysing the sustainable city: nature, urbanisation and the regulation of socio-environmental relations in the UK. Urban Stud 40(7):1183-1206

Williams K, Burton E, Jenks M (2000) Achieving sustainable urban form. E \& FN Spon, London 